\title{
Celebrity Endorsement Solving the Destination Marketing Puzzle
}

Rosma Jolly*

\section{Abstract}

Celebrity endorsement advertising has become an essential element of the advertising strategy. Celebrity endorsement is one of the ways out for marketing problems. An advertisement that uses celebrity endorsers enjoys high recognition among the consumers. It helps the consumer to recognise and recall the brand thus influencing the buying behavior. Since celebrity endorsers create an elevated effect on purchase decision of consumers, producers and retailers always prefer to use celebrities in their advertisement. Further, it will add on to the impact rate if the celebrity endorser is endorsing the product or service for an extended or longer period. Travel and tourism is one of the largest service sectors in India. The main aim of this industry is to develop and promote tourism, maintain and increase the competitiveness of India as a tourist destination, improve and expand existing tourism products to ensure employment generation and thus bringing about economic growth to India. The paper also investigates the various motivating factors of the endorsers taken into consideration to visit the advertised destination. For this, the most important factors of celebrity endorsement were taken note of through extensive literature reviews. Making an inspection on the Swatch Bharat scheme and the involvement of celebrities gives more relevance to the

Assistant Professor, St. Mary's College, Thrissur, Kerala; ros.jos3@gmail.com 
study. The data used was partially primary and partially secondary so that all the aspects could be identified and covered. The data was analysed with the help of statistical package for the social science SPSS with tests such as One sample t-test, ANOVA, Chi Square test, Friedman test.

Keywords: Celebrity Endorsement, tourism destination advertisements, Expertise, Trustworthiness, Similarity, Familiarity, Likeability, Match between the celebrity, transfer meaning, Physical attractiveness.

\section{Introduction}

Advertising has become a vital part of the corporate world today and thus companies are allocating massive part of their revenues to the advertising budget. In the research of Liu et al. (2007), he suggests that promotion of a brand is one of the best effective advertising strategies that are currently available. Using celebrities provides a great deal of help to the companies to create unique ads and gender a positive effect on the attitude and sales intention towards the brand (Ranjbarian, Shekarchizade \& Momeni, 2010). The link between a brand and a product has a positive impact on how the consumers purchase the products and is predominantly facilitated with the use of four major endorsers; they are the CEO, celebrity, expert and the archetypal consumer (Liu et al. 2007). However, statistics claims that as much as $25 \%$ of the chief media trailers and advertisement are endorsed by celebrities (B. Z. Erdogan et al. 2001), and this is the main emphasis upon which this paper is based.

\section{Celebrity Endorsement}

Kamins (1989) defined a celebrity as an individual who is known to the public for his/her achievements in areas other than that of the product class endorsed. A celebrity endorser is "an individual who enjoys public recognition and who uses this recognition on behalf of a consumer good by appearing with it in an advertisement" (McCracken, 1989, p.310). The use of celebrities in advertisements is not a recent phenomenon (Kaikat 1987). The history of celebrity endorsement of products dates back to the 1760s. Looking into the early 1930s, athletes were the major endorsers, but during 1945, 
film icons like Charlie Chaplin were preferred more. When colour TV's became popular that is during 1965, TV personalities and entertainers started becoming popular. Researchers, Robert Clark and Ignatius Horstmann of Boston University studied a collection of 1000 endorsement advertisements from 1920-1970 and found that they were predominantly used by cigarettes, beauty products, beverages and audio equipment (Clark \& Horstman 2003). Agrawal and Kamakura (1995) concluded that the advertisements using celebrities are more effective than the advertisements using noncelebrity. Some studies prove that the use of appropriate celebrities helps increase a positive attitude on consumers.

\section{Eight Major Determinants of Celebrity Endorsement}

After doing an extensive review of literature the determinants of a celebrity endorsement for a tourist destination were brought under eight heads. These determinants were summarised from factors of celebrity endorsement of product as not much study was done in relation to tourist destinations.

a. Expertise: Effective endorsement can be made only if the celebrity has an acceptable level of expertise. Till (2004) stated that celebrity experience should be a key variable for organizations interested in the value of celebrities. Expertise may include competence or qualification of the celebrity. When a celebrity achieves a higher level of expertise, he is considered to be more persuasive and this, in turn, helps to positively alter the consumer's attitude. The importance of expertise is clearly true in the case of tourism and hospitality endorsements because consumers are unaware of the services provided, so an additional opinion of an expert helps them to make a buying decision. According to Pornpitakpan (2003), perceived expertise is created by many factors; chief among them is the celebrity experience.

b. Trustworthiness: In the framework of celebrity endorsement, trustworthiness can be defined as honesty, integrity, and believability of an endorser as perceived by the target audience. Trustworthiness can be the confidence and the acceptance the listener has towards the celebrity and the message in the advertisement (Erdogan et al. (2001, 
p. 40)). Trustworthiness which is built on consumer's association with the endorsed brand has been considered an integral component of celebrity product advertisement framework. Thus, consumer consumption experience is a function of consumers' perception of how reliable the celebrity is (Ohanian, 1990; Silvera and Benedikte 2003). The need for trustworthiness is very much important for hospitality/tourism destination endorsements as the transactions in these sectors are high in the quality of experience (Ibok, N. Ibok 2013). Experience qualities are those that can be understood during or only after consumption (Ibok, N.Ibok 2013). Hence, a celebrity endorsing the tourist destination or a hotel will be considered reliable to stand for the destination even if the consumer has not visited the destination.

c. Similarity: It is the third attractiveness concept and the $S$ in TEARS model. It represents the degree to which an endorser matches an audience in terms of age, gender, ethnicity, etc. Similarity is an important factor because people tend to prefer individuals who share with them common features or traits (Shimp 2010). Similarity is described as "a supposed resemblance between the source and the receiver of the message" (McGuire, 1985). People can be influenced more easily by an endorser who is similar to them. If the celebrity and the consumer have common factors like common interests or lifestyles, a better cohesiveness is created (Erdogan, 1999). Companies also try to create empathy using celebrities (Belch \& Belch, 2001). Using empathy, companies try to create a bond between the celebrity and the consumer (Ibok, N.Ibok2013). Also, the level of persuasiveness is increased by using similarity (Ibok, 2013).

d. Transfer of meaning: Meaning transfer is based on the idea that celebrity endorsers bring their own figurative meaning to the endorsed product and the endorsement process. The cultural meanings that the celebrity will go beyond the person and are passed on to the products (McCracken, 1989; Brierley, 1995). Advertisers hold the belief in employing the 
celebrities for endorsement of the products that consumers consume images of celebrities and advertisers hope that consumer will also consume products endorsed by celebrities. Hirschman (1980) states that symbolic meanings are generated and familiarised to the customers through the production process. McCracken (1986) argues that advertising is one of the ways to forward meanings of personality to products.

e. Familiarity: It is the supposed resemblance as knowledge that a celebrity endorser possesses through exposure (Erdogan, 1999; Belch \& Belch, 2001). Companies should be very careful while choosing a celebrity; companies should make sure to what extent consumers are familiar with the celebrity. The more familiar the consumer is with the celebrity, the more positive the effect will be (Hoekman). It is also well known that consumers, who are more familiar with a celebrity and are more exposed to a celebrity, will automatically like a celebrity more; this is called the mere exposure effect (Zajonc, 1968). Familiarity is effective when there are no longer delays in between the advertisements shown. The effect decreases when there are long exposures of the celebrity and when there are shorter delays between the exposures (Bornstein, 1989).

f. Likeability: Likeability is the "affection for the source as a result of the source's physical appearance and behaviour" (McGuire, 1985,p. 239). McGuire (1985) also states that when people like the celebrity they will also like the accompanying brand and therefore celebrities are used in commercials and advertisements.

g. Match between celebrity and product: Several studies (Cooper, 1984; Forkan, 1980) show that the match-up congruence between celebrity endorser and the product or company is of major importance. This correspondence results in a better recall of the commercial and brand information and will positively affect the transfer influence with regard to the personification of the brand (Rockney \& Green, 1979). Advertising a product via a celebrity who has a relatively high product congruent image, leads to greater 
advertiser and celebrity believability if you would compare it with a less congruent product/celebrity image (Kotler, 1997). The match-up consists of two central terms: the perceived fit and the image of the celebrity (Misra, 1990). When a celebrity has a good image and fit to the product and company, this will lead to greater believability and so effectiveness. By uniting those aspects, you create two advantages, working together for the product (Erdogan, 1999). Celebrities become most effective in advertisements when a match is established between them and the product they are endorsing. Greater acceptance and believability is formed when the celebrity endorser's image and values are similar to the product or service that they are endorsing.

h. Physical attractiveness: Many studies have portrayed a liaison between celebrity's physical attractiveness and attitude changes of consumers. (Caballero and Pride, 1984; Chaiken 1979; Kahle and Homer, 1985). A positive effect on the consumers is created by the attractiveness of the celebrity endorsers. Target viewers can recall, recognise the celebrities mush easily based on the attractiveness of the celebrities. They are more liked by the audience due to attractiveness. Attractiveness also entails concepts such as intellectual skills, personality properties, way of living, athletic performances and skills of endorsers (Erdogan, 1999). Physical attractiveness suggests that a celebrity determines the effectiveness of persuasion as a result of that consumers wanting to be like the endorser and wanting to identify themselves with that endorser (Cohen \& Golden, 1972). When there is a match between brand and celebrity, attractiveness becomes less important and thus the company might choose a less attractive celebrity.

\section{Models for Celebrity Endorsement}

\section{a. TEARS Model:}

TEARS model can be considered as a tool that can be used for evaluating potential celebs so that the most effective celebrity can be used for endorsement. The model is based on mainly two attributes Credibility and Attractiveness (Ohanian, 1990; Till \& 
Busler, 2000). Shimp (2007) divides the two attributes into five subattributes. Two of these pertain to Credibility and three to Attractiveness, together creating the acronym TEARS, which stands for (T) Trustworthiness, (E) Expertise, (A) Physical Attractiveness, (R) Respect and (S) Similarity. Here in this paper other than Respect, all other factors are considered. The factor Respect was not taken into consideration by the pre-questionnaire circulation and factor analysis. Shimp (2007) divides Credibility into two separate, but related, sub-attributes: Trustworthiness and Expertise otherwise called as source creditability model. Again Shimp (2007) divides Attractiveness into three separate sub-attributes: Physical attractiveness, Respect, Similarity otherwise called as source attractiveness model. It is contended that the effectiveness of a message depends on similarity, familiarity and liking for an endorser (McGuire,1985). Researchers say that attractiveness is not only the physical appearance of the celebrity but it includes many other factors like lifestyle, intellectual qualities, familiarity etc. Thus, with reference to the model, six factors were borrowed and inculcated into this study; they were Trustworthiness, Expertise, Physical Attractiveness, Similarity, Familiarity and Liking.

\section{b. Product - Match Model:}

Match-up hypothesis is defined as the consistency between the characteristics of a celebrity endorser and the attributes of the product that they endorse (Misra and Beatty, 1990). According to Erdogan (1999) the Product Match-up Hypothesis maintains the messages conveyed by celebrity image and the product message should be congruent for effective advertising. Further Erdogan (1999) states that advertising a product with a celebrity who has a relatively high product congruent image leads to greater advertiser than an advertisement with a less congruent product/ spokespersons image. He again adds that if celebrities do not have a proper match with the product consumers will tend to believe that the celebrities were paid a handsome amount of money to endorse the product. Thus as the model was found to be of great importance the attribute was considered in the context of a destination advertisement. 


\section{c. McCracken's Meaning Transfer Model (1989):}

McCracken defines this transfer as the translation of the meaning of celebrity to a product, service or brand. The McCracken model makes it possible to explain how celebrities transmit an extensive set of associations to the brands they endorse. Therefore, before companies select celebrities to represent their brands, they need to ensure that the person conveys the right meaning (FleckDousteyssier and Korchia, 2006). The consumers admire celebrities maybe because the celebrity is physically attractive or maybe he has done what the consumer wants to view. But this is not always the case, consumers also looks into the fact that the celebrity provides meanings of the product or service to the consumer. Thus with the reference of the above three models and with pre-testing of questionnaire eight attributes were come up for the study. With these factors a cross case analysis was done to find out the reactions of the different occupation group towards these celebrity attributes.

\section{Methodology}

\section{Objectives of the study}

- To identify the various factors of celebrity endorsers that motivates people to visit the advertised tourist destination

- To determine the category of occupants who are influenced by celebrity endorsement

\section{Hypothesis of the study}

H1: There is a significant difference between occupation and perception of getting attracted to a destination, recognizing and recalling, identifying destination details and then visiting the destination when endorsed by a celebrity.

H2: Expertise, Trustworthiness, Similarity, Familiarity, Likeability, Match between, Transfer of meaning and Physical attractiveness of the celebrity endorser influence the customers to visit the advertised destination

\section{Sampling method}

The sample consists of 250 people from across Bangalore. The sampling methods used to select the sample are convenience 
sampling method (non-probabilistic sampling method) \& stratified sampling as equal proportion of questionnaire is given to people of different occupations like Teacher, IT employee, Business, Students and others.

\section{Tools for the study}

Primary data was collected with the help of questionnaire method. The questionnaire was divided into three parts the first deals with demographic data of the respondents, the second section relates to the opinions of the respondents on celebrity endorsement in tourism advertisements and the third section focuses on the suggestions of the respondents if they want Bangalore to be promoted by a celebrity. Contents of the questionnaire were validated by experts' opinion both from academia and industry. Secondary data was collected from journals, books, newspapers etc.

\section{Analysis, results and findings}

Opinion Towards Celebrity Endorsed Tourism Advertisements Across Occupation In Influencing Consumer On Decision Making Process

H1: There is a significant difference across occupations and perception of getting attracted to a destination, recognizing and recalling, identifying destination details and then visiting the destination when endorsed by celebrities.

Table showing the mean and std.dev of opinions of celebrity endorsement across occupation

\begin{tabular}{|c|c|c|c|c|c|c|c|}
\hline & \multicolumn{6}{|c|}{ Occupations } \\
\hline & & 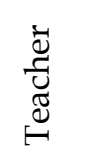 & 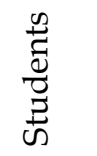 & 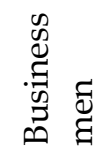 & 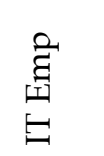 & $\frac{\infty}{\stackrel{\Xi}{ \pm}}$ & $\underset{\ominus}{\tilde{0}}$ \\
\hline $\begin{array}{l}\text { I visit places } \\
\text { that have } \\
\text { been } \\
\text { endorsed by } \\
\text { celebrities }\end{array}$ & $\begin{array}{l}\text { Mean } \\
\text { Std. } \\
\text { Dev }\end{array}$ & $\begin{array}{l}3.16 \\
1.201\end{array}$ & $\begin{array}{l}2.90 \\
0.886\end{array}$ & $\begin{array}{l}3.10 \\
1.147\end{array}$ & $\begin{array}{l}3.26 \\
1.065\end{array}$ & $\begin{array}{l}3.12 \\
1.189\end{array}$ & $\begin{array}{l}3.11 \\
1.101\end{array}$ \\
\hline
\end{tabular}




\begin{tabular}{|l|l|l|l|l|l|l|l|}
\hline $\begin{array}{l}\text { I am } \\
\text { attracted to a } \\
\text { destination } \\
\text { that has a } \\
\text { familiar face } \\
\text { in its Ad }\end{array}$ & $\begin{array}{l}\text { Std. } \\
\text { Dev }\end{array}$ & 1.307 & 1.210 & 1.136 & 1.044 & 1.107 & 1.160 \\
\hline $\begin{array}{l}\text { I can more } \\
\text { promptly } \\
\text { recognise } \\
\text { and recall a } \\
\text { destination } \\
\text { that has a } \\
\text { celebrity in } \\
\text { its Ad }\end{array}$ & $\begin{array}{l}\text { Std. } \\
\text { Dev }\end{array}$ & 1.178 & 1.058 & 1.136 & 0.990 & 1.096 & 1.093 \\
\hline $\begin{array}{l}\text { I pay more } \\
\text { attention to } \\
\text { tourism } \\
\text { product } \\
\text { details } \\
\text { if it is } \\
\text { endorsed by } \\
\text { a } \\
\text { celebrity }\end{array}$ & $\begin{array}{l}\text { Std. } \\
\text { Dev }\end{array}$ & 1.391 & 1.190 & 1.063 & 1.062 & 1.252 & 1.194 \\
\hline
\end{tabular}

\section{Interpretation:}

From the Table 3.1.1 it can be concluded that across occupational groups people disagree that they will surely visit a destination if endorsed by a celebrity. Only the student's agreed to the statement but which is close to the average rating. Across the occupational groups the statement that the respondents will get attracted to a destination if they see a familiar face is agreed. It was agreed across the occupations that if tourism advertisement is endorsed by a celebrity they can quickly recall and recognise the destination and the attributes of the destination. According to the means one can find that, teachers and others occupational group is almost 3 which means they may or may not pay attention to product details if endorsed by a celebrity, where as students and businessmen feel that they will pay attention to the product details endorsed by a celebrity. However, IT employees completely disagree to the same. 
Table showing the dependence of occupation and opinion of celebrity endorsement

\begin{tabular}{|c|c|c|c|c|c|c|c|c|}
\hline 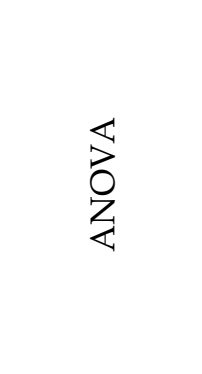 & 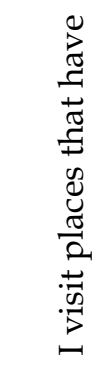 & 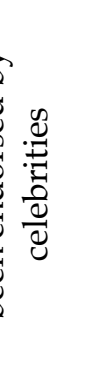 & 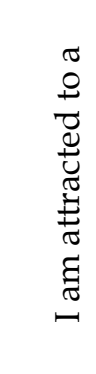 & 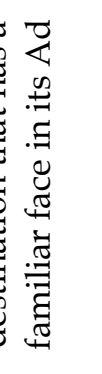 & 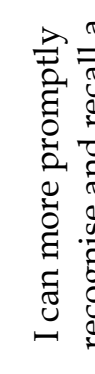 & 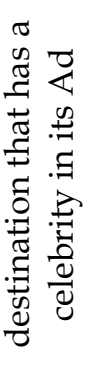 & 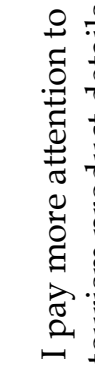 & 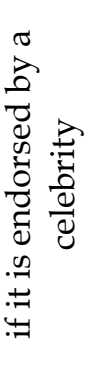 \\
\hline Source & $\begin{array}{c}\mathrm{F} \\
\text { Stat }\end{array}$ & $\begin{array}{c}\mathrm{P} \\
\text { Value }\end{array}$ & $\begin{array}{c}\text { F } \\
\text { Stat }\end{array}$ & $\begin{array}{c}\mathrm{P} \\
\text { Value }\end{array}$ & $\begin{array}{c}\mathrm{F} \\
\text { Stat }\end{array}$ & $\begin{array}{c}\mathrm{P} \\
\text { Value }\end{array}$ & $\begin{array}{c}\mathrm{F} \\
\text { Stat }\end{array}$ & $\begin{array}{c}\mathrm{P} \\
\text { Value }\end{array}$ \\
\hline Occupation & 0.711 & 0.585 & 0.509 & 0.729 & 0.883 & 0.475 & 0.527 & 0.716 \\
\hline
\end{tabular}

\section{Interpretation:}

It can be inferred from Table 4.6.2 that there is no significant difference between the occupational group in the perception of visiting a destination if endorsed by celebrity as determined by ANOVA having a $\mathrm{p}$ value 0.585 which is greater than 0.05 thus accepting the null hypothesis. No significant difference between the occupational group in the opinion that they get attracted to a destination when endorsed by a celebrity was found as determined by ANOVA having a $\mathrm{p}$ value of 0.729 which is greater than 0.05 thus accepting the null hypothesis.

There is no significant difference between the occupational groups in the perception that celebrity endorsement helps to recall and recognise tourist destination advertisements with a $p$ value of 0.475 which is determined by ANOVA thus accepting the null hypothesis.

A $p$ value of 0.716 in ANOVA $(0.716>0.05)$ can be interpreted in such a way that there is no significant difference between occupational group in the opinion of giving attention to the product details if endorsed by a celebrity thus accepting the null hypothesis. 


\section{Factors of Celebrity Endorsers That Motivates People to Visit the Advertised Tourist Destination}

H2: Expertise, Trustworthiness, Similarity, Familiarity, Likeability, Match between, transfer of meaning and Physical attractiveness of the celebrity endorser influence the customers to visit the advertised destination

H2(a): Expertise of a celebrity in his/her field can influence the customer to visit the destination

H2(b): Trustworthiness of a celebrity can influence the decision to visit a tourist destination.

H2(c): Similarity between the consumer and the celebrity can influence the decision to visit a tourist destination.

H2(d): Familiarity of the celebrity can influence the consumer to visit the destination.

$\mathrm{H} 2(\mathrm{e})$ : Likeability of the celebrity can attract the tourist to a destination.

H2(f): Match between the celebrity and the product can influence the consumer's decision to go to a destination

$\mathrm{H} 2$ (g): Transfer of meaning from the product to the consumers by the celebrity can influence the tourists to visit tourist destinations.

H2(h): Physical attractiveness of a celebrity can influence the consumers to make decisions to visit a destination. 
Table showing the descriptive analysis and one sample $t$ test results of factors of celebrity endorser

\begin{tabular}{|c|c|c|c|c|}
\hline & & & T Value & P Value \\
\hline \multirow{2}{*}{$\begin{array}{l}\text { Expertise of a celebrity in } \\
\text { his/her field }\end{array}$} & Mean & 2.58 & \multirow[t]{2}{*}{-5.676} & \multirow[t]{2}{*}{0.000} \\
\hline & SD & 1.170 & & \\
\hline \multirow[t]{2}{*}{ Trustworthiness of a celebrity } & Mean & 2.58 & \multirow[t]{2}{*}{-5.707} & \multirow[t]{2}{*}{0.000} \\
\hline & SD & 1.153 & & \\
\hline \multirow{2}{*}{$\begin{array}{l}\text { Similarity between you and the } \\
\text { celebrity }\end{array}$} & Mean & 2.91 & \multirow[t]{2}{*}{-1.281} & \multirow[t]{2}{*}{0.201} \\
\hline & SD & 1.135 & & \\
\hline \multirow[t]{2}{*}{ Familiarity of a celebrity } & Mean & 2.77 & \multirow[t]{2}{*}{-3.049} & \multirow[t]{2}{*}{0.003} \\
\hline & SD & 1.182 & & \\
\hline \multirow[t]{2}{*}{ Likeability of the celebrity } & Mean & 2.81 & \multirow[t]{2}{*}{-2.691} & \multirow[t]{2}{*}{0.008} \\
\hline & SD & 1.128 & & \\
\hline \multirow{2}{*}{$\begin{array}{l}\text { Match between the celebrity } \\
\text { and the product }\end{array}$} & Mean & 2.74 & \multirow[t]{2}{*}{-3.738} & \multirow[t]{2}{*}{0.000} \\
\hline & SD & 1.117 & & \\
\hline \multirow{2}{*}{$\begin{array}{l}\text { Transfer meaning to the } \\
\text { product }\end{array}$} & Mean & 2.72 & \multirow[t]{2}{*}{-4.072} & \multirow[t]{2}{*}{0.000} \\
\hline & SD & 1.072 & & \\
\hline \multirow{2}{*}{$\begin{array}{l}\text { Physical attractiveness of a } \\
\text { celebrity }\end{array}$} & Mean & 2.99 & \multirow[t]{2}{*}{-0.165} & \multirow[t]{2}{*}{0.869} \\
\hline & SD & 1.149 & & \\
\hline
\end{tabular}

\section{Interpretation:}

\section{Statement 1: Expertise of a celebrity in his/her field}

It can be viewed that the mean is 2.58 which is less than 3 (significantly below average ratings) thus concluding that there is a general agreement to the factor expertise of the celebrity.

One sample $t$ test was done to test the hypothesis it was found that the $p$ value is 0.000 which is less than $0.05(0.000<0.05)$. Such a $p$ value indicates to reject the null hypothesis thus concluding that the consumers would look into expertise of the celebrity as one factor when endorsing a tourist destination. 
Statement 2: Trustworthiness of a celebrity can influence your decision to visit a place.

It is found that the mean is 2.58 which is less than 3 (significantly below average ratings) thus concluding that there is a general agreement to the factor trustworthiness of the celebrity.

One sample $t$ test was done to test the hypothesis it was found that the $\mathrm{p}$ value is 0.000 which is less than $0.05(0.000<0.05)$. Such a $\mathrm{p}$ value indicates to reject the null hypothesis thus concluding that the consumers would look into trustworthiness of the celebrity as one factor when endorsing a tourist destination.

Statement 3: Similarity between you and the celebrity can influence your decision to visit a place.

It can be viewed that the mean is 2.91 which is less than the 3 (nearing the average ratings) thus concluding that there is almost a neutral response to the factor similarity of the celebrity.

One sample $t$ test was done to test the hypothesis it was found that the $p$ value is 0.201 which is greater than $0.05(0.201>0.05)$. Such a $p$ value indicates to accept the null hypothesis thus concluding that the consumers would not look into how similar the celebrity is to the consumer when endorsing a tourist destination.

\section{Statement 4: Familiarity of the celebrity can influence your visit to a destination}

It can be viewed that the mean is 2.77 which is less than 3 (significantly below average ratings) thus concluding that there is almost an agreement to the factor familiarity of the celebrity.

One sample $t$ test was done to test the hypothesis it was found that the $\mathrm{p}$ value is 0.003 which is less than $0.05(0.003<0.05)$. Such a $p$ value indicates to reject the null hypothesis thus concluding that the consumers would consider familiarity of the celebrity as one factor when endorsing a tourist destination. 
Statement 5: Likeability of the celebrity can attract you to a destination

It can be viewed that the mean is 2.81 which is less than 3 (significantly below average ratings) thus concluding that there is almost a general agreement to the factor likeability of the celebrity.

One sample $t$ test was done to test the hypothesis it was found that the $p$ value is 0.008 which is less than $0.05(0.008<0.05)$. Such a $p$ value indicates to reject the null hypothesis thus concluding that the consumers would like to see celebrities who are loved by them.

Statement 6: Match between the celebrity and the product can influence your decision to go to a destination

It can be viewed that the mean is 2.74 which is less than 3 (significantly below average ratings) thus concluding that there is almost a general agreement to the factor match between the tourism product and the celebrity.

One sample $t$ test was done to test the hypothesis it was found that the $\mathrm{p}$ value is 0.008 which is less than $0.05(0.008<0.05)$. Such a $\mathrm{p}$ value indicates to reject the null hypothesis thus concluding that the consumers would like to see a match between the celebrity and the tourism product which they endorse.

Statement 7: Celebrities who provide or transfer meaning to the product can influence your visiting intentions

It can be viewed that the mean is 2.72 which is less than 3 (significantly below average ratings) thus concluding that there is almost a general agreement to the factor transferring of meaning from the celebrity to the tourism product.

One sample $t$ test was done to test the hypothesis it was found that the $p$ value is 0.000 which is less than $0.05(0.000<0.05)$. Such a $p$ value indicates to reject the null hypothesis thus concluding that the consumers would want the celebrities to transfer some meaning about the tourist destination. 


\section{Statement 8: Physical attractiveness of a celebrity can influence your decision to visit a destination}

It can be viewed that the mean is 2.99 which is almost or 3 (significantly equal to the average ratings) thus concluding that there is almost a general disagreement to the factor physical attractiveness of the celebrity.

One sample $t$ test was done to test the hypothesis it was found that the $\mathrm{p}$ value is 0.869 which is greater than $0.05(0.869>0.05)$. Such a $\mathrm{p}$ value indicates to accept the null hypothesis thus concluding that consumers would not take a decision looking at the physical attractiveness of the celebrity.

\section{Cross-case analysis}

Cross-case analysis is an analysis that includes a check of more than one case; this can be either a variable-oriented or case-oriented analysis. Here each of the occupational group is analyzed with each of the celebrity endorsement attributes to find which occupational group favours to which attribute thus helping the marketer at the time of target marketing of a destination.

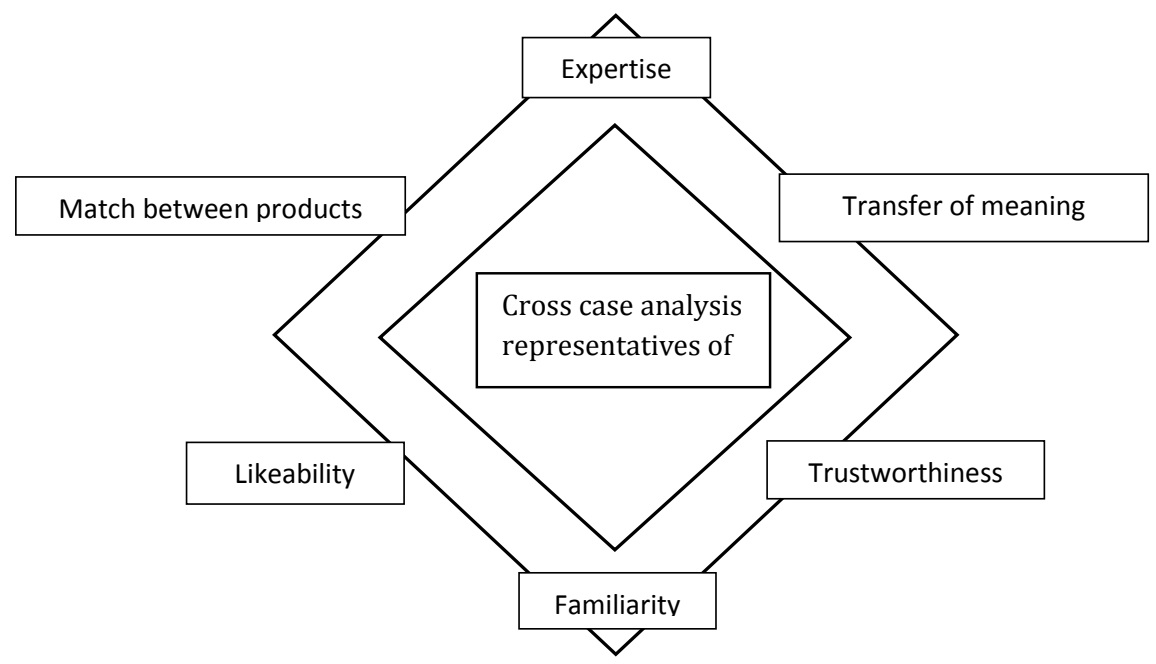

Fig 1 Cross case analysis of representatives of Teacher 
The teacher representatives felt that one of the major attributes that a celebrity endorser should have when endorsing a tourist destination are expertise in his/her own field. The teacher fraternity also felt that it is very important to have a match between the product and the celebrity, the endorser should be familiar and trustworthy and preferably likable and ultimately pointed out the importance of transfer the message and the meaning of the advertisement. The teacher respondents felt that physical attractiveness of the celebrity has not much role to play in their preferential factor list.

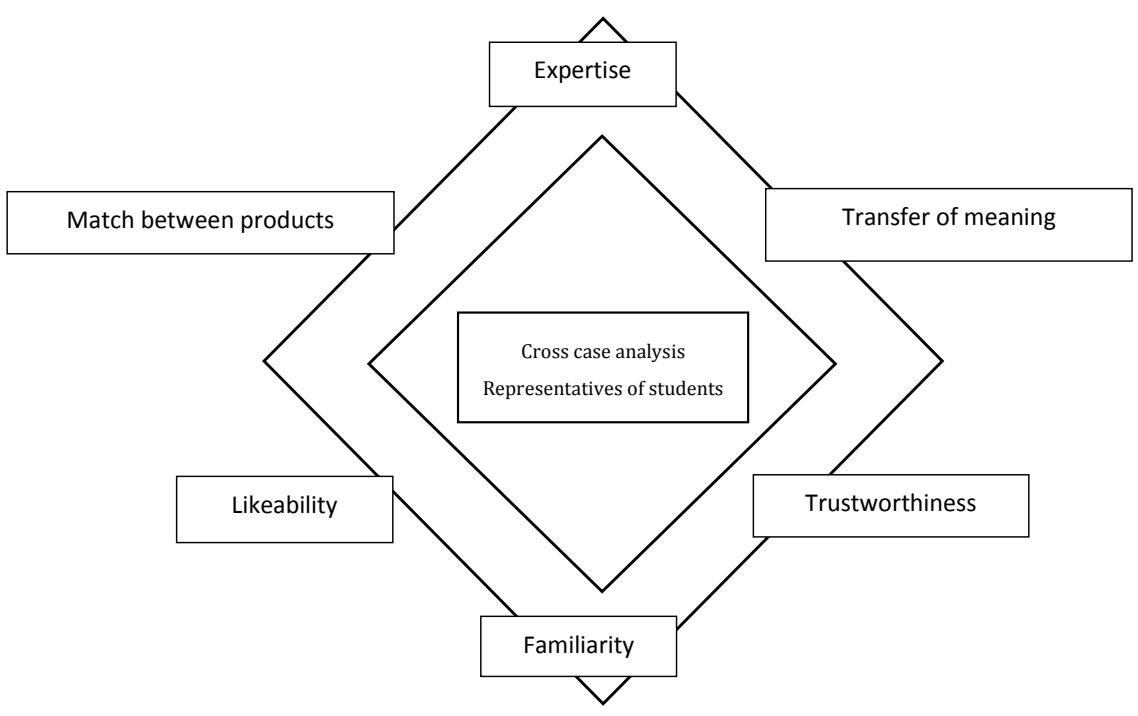

Fig 2 Cross case analysis of representatives of Students:

The student representatives also felt the same as that of the teachers. They emphasized on expertise of celebrities, match between the product and the celebrity, familiar and trustworthy and preferably likable and the importance of transfer the message and the meaning of the advertisement accurately. Again it was found that physical attractiveness of the celebrity didn't make much affect on the group. 


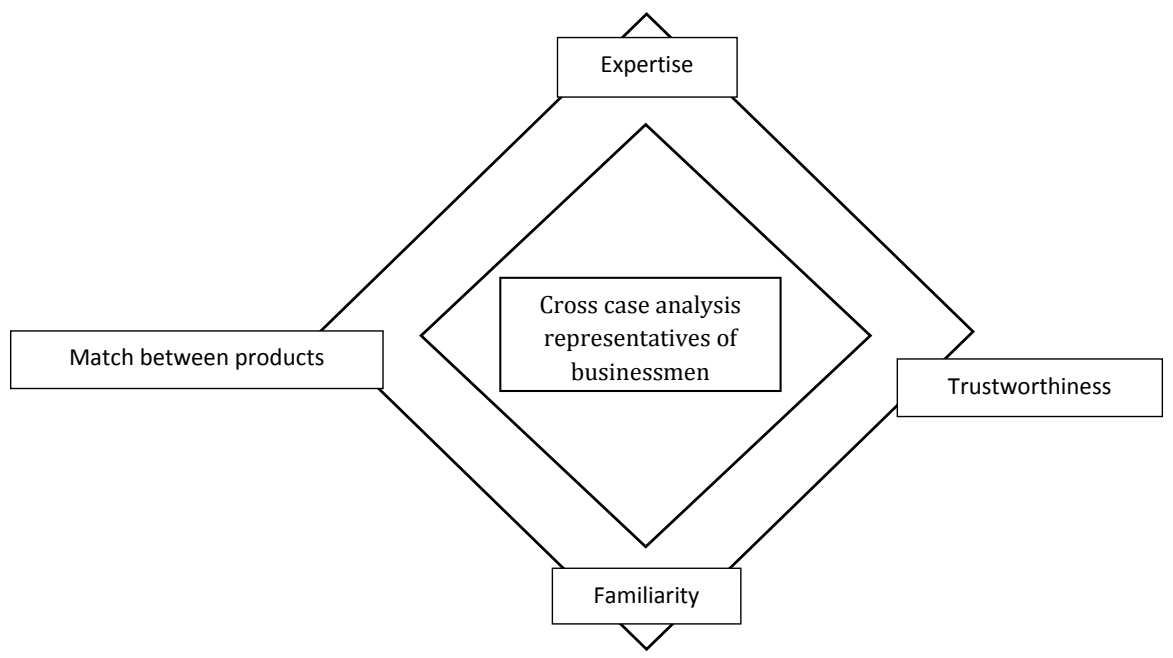

Fig 3 Cross case analysis of representatives of Businessmen:

The businessmen representatives had a slightly different opinion. They highlighted on expertise of the celebrities, match between the product and the celebrity, familiarity and trustworthiness but they did not feel that likable and transfer of meaning of the advertisement was necessary for a celebrity endorsing a destination. Again physical attractiveness of the celebrity did not make any affect on the group.

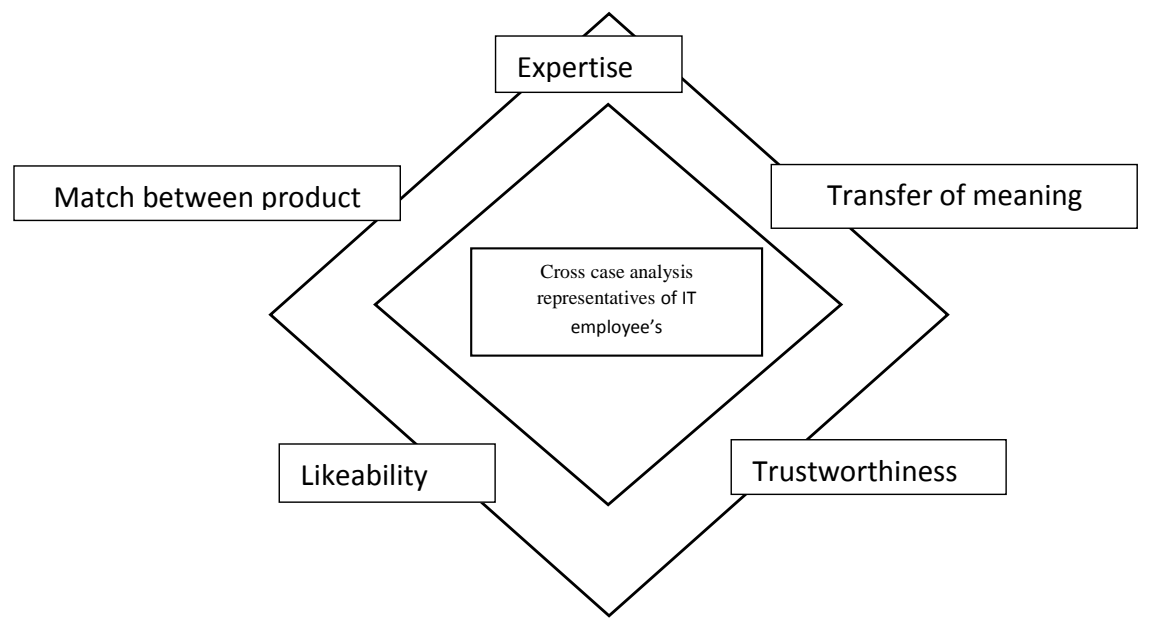

Fig 4 Cross case analysis of representatives of IT employee: 
IT employee representatives felt the same as that of the teachers and students except they felt familiarity is not an important attribute for endorsing a destination. Physical attractiveness of the celebrity also didn't make any affect on the group.

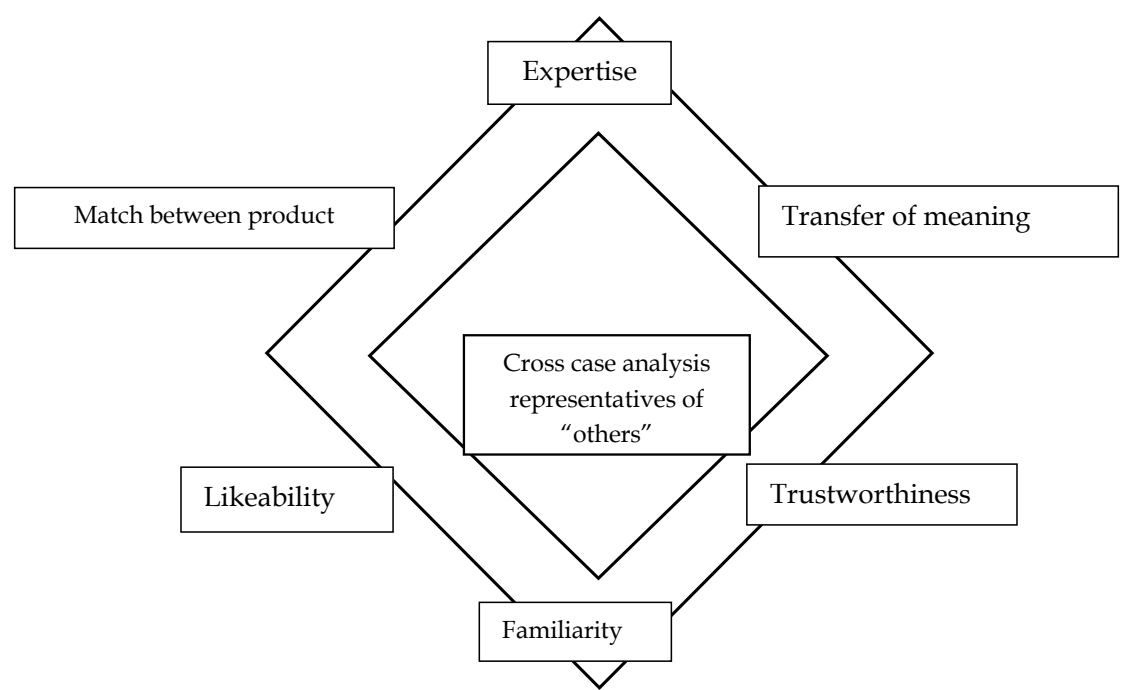

Fig 5 Cross case analysis of representatives of "others"

The "other" group included HR people, people in advertising, doctors, and people in the medical field, etc. They felt the same as that of the teachers and students. They emphasized on expertise of the celebrities, match between the product and the celebrity, familiarity and trustworthiness and preferably likable and the importance of transfer of meaning of the advertisement accurately. Here also physical attraction did not have an effect.

\section{Implications for celebrity endorsement}

Some of the major implications that can be drawn from this paper are given below:

- The destination advertisement would be more appealing to the consumers if there is a match between the destination and the celebrity. For example, if the destination to be promoted is Bangalore it is better to select an endorser who 
is a native of Bangalore and a person who loves travelling. This would give a more authentic feeling for the customers.

- As the study finds out that physical appearance has very little or no impact on the decision-making process it is better for the organisations not to invest money on celebrities, just by beauty or physical appearance.

- Another implication of this research was that the student community was more attracted towards celebrity destination endorsements, the advertisement can be targeted on student's magazines as children have the decision-making power nowadays.

- After a detailed study of Swatch Bharath, it was found that the celebrity advertising strategy has helped to increase the GDP rate and the foreign exchange rate. Here the strategy was a bit trickier, where celebrities were involved with no cost as it was for a social cause but the publicity boosted up as more than six celebrities were involved.

- One major inference is that the use of a celebrity during advertising of a product does not necessarily lead to a positive in the decision making. However the use of a celebrity does help the respondents to notice the advertisement and also gives a glamorous effect to the advertisements.

- With the literature review, it can also be concluded that celebrity endorsement can be either used for a new product or for a mature product so that the destinations can differentiate from that of its competitors.

- The study also concludes that celebrities with a good image in public will be able to boost the acceptance of the product among the customers and helps the customers to recall easily and remember the advertisement.

\section{Conclusion}

Celebrity endorsers are used by advertisers to differentiate and position their products or services from their competitors. It has become a trend nowadays to rope in a celebrity endorser and 
endorse their place and differentiate the destination from that of their competitors and to create direct awareness of their product by showcasing their own unique selling propositions. This study helps to understand the response of tourists in Bangalore towards celebrity endorsement and to explore the effect of celebrity endorsers on them. The research results suggest that celebrity endorsement helps to bring in awareness about the destination, recognise the place and helps to recall by creating an association with the celebrity. Thus it should be understood that celebrity endorsement helps to create awareness but need not directly translate the awareness to visiting the destination or building a liking to the destination. Celebrity endorsement as found in the study may help the consumer to filter choices from the many destinations he has in mind to visit. Billions of money is spent when celebrities are asked to endorse a product, so it is very important for the marketers to choose the right celebrity and to use these celebrities in the right way. One major finding from the research is that a combination of celebrities and the unique attributes of the destination would help in translating the awareness to visiting the destination.

\section{References}

Ahmed, A., Mir, F. A., \& Farooq, O. (2012). Effect of celebrity endorsement on customers' buying behavior; a perspective from pakistan. Interdisciplinary Journal of Contemporary Research in Business, 4(5), 584-592. http://search.proquest.com/ docview $/ 1115314157$ ?accountid $=38885$

Al-Ghamdi, M. (2005). Saudi arabian television (first channel) touristic programs: Uses and gratifications and perceptions of the programs' effect by saudi tourists who spend their summer vacations domestically. The University of Kansas. ProQuest Dissertation sand Theses ,313313p. http://search.proquest.com/ docview/ 304990762 ?accountid=38885(304990762).

Amos, C., Holmes, G., \& Strutton, D. (2008). Exploring the relationship between celebrity endorser effects and advertising effectiveness. International journal of advertising, 27(2), 209-234. Retrieved from http://hull.aug.edu/ thoughtleadership/ research/ Amos- Holmes Strutton-IJA-2008.pdf 
Anghel, C. (2009). The effect of celebrity endorsements on giftgiving purchases: An application of the elaboration likelihood model . Graduate School Theses and Dissertations, Retrieved from http:// scholarcommons.usf.edu/etd/1834/.

Busler, M. (2002). Product differentiation, celebrity endorsements and the consumer's perception of quality. Drexel University. ProQuest Dissertations and Theses,138-138 p. Retrieved from http:// search.proquest.com/docview $/ 304801722$ ?accountid $=38885$ (304801722)

Doss, S. (2011). The transference of brand attitude: The effect on the celebrity endorser. Journal of Management and Marketing Research, 7, 1-11. Retrieved from http://search.proquest.com/ docview $/ 864625507$ ?accountid $=38885$

D'Souza, D. N. (2012). Follow the Stars. Indian Express. Retrieved from http://www.indianexpress.com/news/follow-thestars $/ 932626 / 0$

Dzidrov, M. (2010). Advertising industry - trends, opportunities and challenges with special emphasis of chinese tourism. UTMS Journal of Economics, 1(2), 85-90. Retrieved from http:/ / search.proquest.com/docview / 822929590?accountid=38 885

Eltom , H. (2006). Celebrity endorsement branding-linking fragrances to celebrities. (Degree thesis). Retrieved from http://urn.kb.se/ resolve?urn=urn:nbn:se:sh:diva-1337

Fullerton, J. A., Kendrick, A., \& Kerr, G. (2009). Australian student reactions to US tourism advertising: A test of advertising as public diplomacy. Place Branding and Public Diplomacy, 5(2), 141150. doi: http://dx.doi.org/10.1057/pb.2009.7

Garland, R., Jan , C., \& Andrew , H. (2006). Celebrity athlete endorsement: What drives choice?. Australia New Zealand Marketing Academy Conference (ANZMAC).

Ghani, U. M., \& Kakakhel, T. (2011). The impact of celebrity endorsement on the youth of pakistan. International Conference on Business and Economics Research, 16, 79-83. Retrieved from http://www.ipedr.com/vol16/15-ICBER2011-A10017.pdf 
Glover, P. (2009). Celebrity endorsement in tourism advertising: Effects on destination image. Journal of Hospitality and Tourism Management, 16 1: 16-23.

Hakimi, B., Abedniya , A., \& Zaeim, M. (2011). Investigate the impact of celebrity endorsement on brand image. European Journal of Scientific Research, 58(1), 116- 132. Retrieved from http://www.eurojournals.com/ ejsr.htm

Hedgpeth.D.(2002). Tourism; Separate Effort by Smithsonian, AARP Will Target Group's Members. The Washington Post.

Homegrown icons: Local celebrity is key in the discriminating world of Quebec advertising. (1996). Marketing Magazine, 101(22), 11-11,12.

Ilicic, J., \& Webster, C. M. (2011). Effects of multiple endorsements and consumer-celebrity attachment on attitude and purchase intention. Australasian Marketing Journal, 19(4), 230237.http:// search.proquest.com/docview/899259609?accounti $\mathrm{d}=38885$

Kannan,P.( 2006). Star-struck tourism. Express travel world.

Kumar,A.(2010). Celebrity endorsement and its Impact on consumer buying behaviour. Bournemouth University. Retrieved from http:/ / ssrn.com/abstract $=1802531$

KV, D. G. (2012). Effects of celebrity endorsement on consumer buying behavior and branding of a brand. ZENITH International Journal of Business Economics \& Management Research, 2(7), 92102.

Lin,J.(2005). Tourism numbers boosted by celebrity endorsement .Taipei times.

Magnini ,V. P., Honeycutt ,E. D., \& Cross ,A. M. (2008). Understanding the use of celebrity endorsers for hospitality firms. Journal of Vacation Marketing, 14(1):57-69

Md Zabid, A. R., Nallamuthu, J., \& Sidin, S. M. (2002). Perceptions of advertising and celebrity endorsement in malaysia. Asia Pacific Management Review, 7(4) Retrieved from http:// search.proquest.com/docview/1115664662? accountid=3 8885

Mehta, A. (1999). Celebrities in advertising. In J. Jones (Ed.), The advertising business: Operations creativity media planning integrated communications. (pp. 193-209). Thousand Oaks, CA: SAGE Publications, Inc. doi: 10.4135/9781452231440.n19 
Mulec, I. (2010). Promotion as a tool in sustaining the destination marketing activities. TURIZAM, 14(1), 13-21. Retrieved from http://www.dgt.uns.ac.rs/turizam/arhiva/vol_1401_mulec.p df

Norman,S.\& Pettersen,M.(2008). A qualitative study investigating Australian Tourism Companies' promotional efforts on the Japanese market. hh.diva- portal.org/smash/get/ diva2:238334/ FULLTEXT01

Pandey, V. (2011). Impact of celebrity endorsement on young generation through tv advertisement. VSRD-IJBMR, 1(4), 226231. Retrieved from http://www.vsrdjournals.com/MBA/Issue/2011_6_June/3_Vi vek_Kr_Pandey_Researc h_Article_June_2011

Ranjbarian, B., Shekarchizade , Z., \& Momeni , Z. (2010). Celebrity endorser influence on attitude toward advertisements and brands . European Journal of Social Sciences, 13(3), 399-407.

Reid, R. D., \& Bojanic, D. C. (2009). Hospitality marketing management. (5 ed., p. 400). New jersey: John wiley \& sons, INC. Retrieved from http:/ / books.google.co.in

Rodriguez, K. (2008). Apparel brand endorsers and their effects on purchase intentions: A study of philippine consumers. Philippine Management Review , 15, 83-99.

Roozen, I.(2008).The Relative Effectiveness of Celebrity Endorsement for Beauty, High- and Low Involvement Product Print Advertisements. http://www.escpeap.net/conferences/marketing/2008_cp/Materiali/Paper/Fr/ Roozen.pdf

Roy,S., Gammoh. B.,\& Koh,A.,(2012). Predicting the effectiveness of celebrity endorsement using Balance theory. Journal of Customer Behaviour, 11 1: 33-52.

Shimp, T.(2010). Advertising, Promotion, and Other Aspects of Integrated Marketing Communications.(8ed.,p.253). Cengage Learning

Silvera, D. H., \& Austad, B. (2004). Factors predicting the effectiveness of celebrity endorsement advertisements. European Journal of Marketing, 38(11), 1509-1526. Retrieved from 
http:// search.proquest.com/docview/237025494?accountid=38 885

Sindhu, B. (2011). Is celebrity endorsement a Midas touch or a Landmine. Gurukul Business Review (GBR), 7, 81-86. http://www.gkvharidwar.org/journals/gbr_7/Paper_10.pdf Sirothia,A. (2012,Jun 10). State not to rope in star brand ambassador.TNN.

Thomas,J.(2008).Advertising Effectiveness. Decision Analyst, Inc. http://www.decisionanalyst.com/publ_art/adeffectiveness.da i

Toland, B. (2003). Tourism in Pennsylvania takes new tack; internet, magazine ads to replace TV. Knight Ridder Tribune Business News. Retrieved from http://search.proquest.com/ docview/ 461457357 ?accountid $=38885$

Tourism in Brazil in the digital media. (2009). Info - Prod Research (Middle East). Retrieved from http://search.proquest.com/ docview $/ 457397028$ ? accountid $=38885$

Um, N. (2008). Exploring the effects of single vs. multiple products and multiple celebrity endorsements. Journal of Management and Social Sciences, 4(2), 104-114. Retrieved from http://www.biztek.edu.pk/downloads/research/jmss_v4_n2/ 4 Are You Sharing Your Celebrity Endorser.pdf

Van, d. V. (2009). Celebrity endorsement effectiveness for print destination advertising. European Journal of Tourism Research, 2(2), 186-189.

Waldt, V. D., Loggerenberg, M. V., \& Wehmeyer, L. (2009). Celebrity endorsements versus created spokespersons in advertising: a survey among students. South African Journal of Economic and Management Sciences, , 12(1),100-114

Yannopoulos, P. (2012). Celebrity advertising: Literature review and propositions. World Review of Business Research , 2(4), 24-36.

Zafar, Q. (n.d.). Impact of celebrity advertisement on customers' brand perception and purchase intention. Asian Journal of Business and Management Sciences, 1(11), 53- 67. Retrieved from www.ajbms.org

Zoubi, M., \& Bataineh, M. (2011). The effect of using celebrities in advertising on the buying decision "empirical study on students in Jarash private university. American Journal of Scientific Research, (13), 59-70. 


\section{Websites:}

Christina S. Simmers, Datha Damron-Martinez, \& Diana L. Haytko.(2009,April). Examining the Effectiveness of Athlete Celebrity Endorser Characteristics and Product Brand Type: The EndorserS expertise Continuum. Retrieved fromhttp:// hdl.handle.net/2027/spo.6776111.0001.110

Diana Burns. Introduction to Advertising .Retrieved from http:// www.scribd.com/doc/23711241/9/ADVERTISINGTYPES

Karina P. Rodriguez.(2008). Apparel brand endorsers and their effects on purchase intentions: a study of philippine consumers. Retrieved from http://journals.upd.edu.ph/ index.php/ pmr/ article/viewfile/1503/1458

Nigel Morgan, Annette Pritchard. Advertising in Tourism and leisure. Retrieved from http://www.scribd.com/ doc/ 14842129/ Advertising-in-Leisure-and-Tourism

Puja khatri.(December,2006). Celebrity Endorsement : A Strategic Promotion Perspective. Retrieved from http:// www.satishserial.com/ issn0972-9348/finaljournal03.pdf

Samuel Doss. The transference of brand attitude: the effect on the celebrity endorser .Retrieved from http:// www.aabri.com/ manuscripts/10636.pdf

Nigel Morgan, Annette Pritchard. Advertising in Tourism and leisure. Retrieved from http://www.scribd.com/ doc/14842129/Advertising-in-Leisure-and-Tourism 